\title{
How Will the COVID-19 Pandemic Affect the Future of Urban Life? Early Evidence from Highly-Educated Respondents in the United States
}

\author{
Matthew Wigginton Conway ${ }^{1}{ }^{(\mathbb{D}}$, Deborah Salon ${ }^{1, * \mathbb{C}}$, Denise Capasso da Silva ${ }^{2}{ }^{(D)}$ and \\ Laura Mirtich ${ }^{1}$ (1) \\ 1 School of Geographical Sciences and Urban Planning, Arizona State University, Tempe, AZ 85287, USA; \\ mwconway@asu.edu (M.W.C.); lmirtich@asu.edu (L.M.) \\ 2 School of Sustainable Engineering and the Built Environment, Arizona State University, \\ Tempe, AZ 85287, USA; denise.silva@asu.edu \\ * Correspondence: dsalon@asu.edu
}

Received: 3 September 2020; Accepted: 19 October 2020; Published: 22 October 2020

\begin{abstract}
Attitudes and habits are extremely resistant to change, but a disruption of the magnitude of the COVID-19 pandemic has the potential to bring long-term, massive societal changes. During the pandemic, people are being compelled to experience new ways of interacting, working, learning, shopping, traveling, and eating meals. Going forward, a critical question is whether these experiences will result in changed behaviors and preferences in the long term. This paper presents initial findings on the likelihood of long-term changes in telework, daily travel, restaurant patronage, and air travel based on survey data collected from adults in the United States in Spring 2020. These data suggest that a sizable fraction of the increase in telework and decreases in both business air travel and restaurant patronage are likely here to stay. As for daily travel modes, public transit may not fully recover its pre-pandemic ridership levels, but many of our respondents are planning to bike and walk more than they used to. These data reflect the responses of a sample that is higher income and more highly educated than the US population. The response of these particular groups to the COVID-19 pandemic is perhaps especially important to understand, however, because their consumption patterns give them a large influence on many sectors of the economy.
\end{abstract}

Keywords: COVID-19; future of transport; teleworking

\section{Introduction}

The COVID-19 pandemic has caused dramatic changes in society, and especially in our transportation choices. Since mobility is closely related to the spread of COVID-19 [1,2], travel is down dramatically, with particularly large reductions in transit and air travel. Teleworking is now commonplace, at least among white-collar workers. Walking and cycling, both for transport and recreation, are increasingly popular as they allow travelers to avoid direct contact with others. Online shopping, even for groceries, is ubiquitous. Many of these changes were happening already, but COVID-19 has pressed the fast-forward button [3,4].

Attitudes and habits are extremely resistant to change (e.g., [5-7]), but a disruption of this magnitude has the potential to bring long-term, massive societal changes. During the pandemic, people are being compelled to experience new ways of interacting, working, learning, shopping, traveling, and eating meals.

Going forward, a critical question is whether and how these experiences have actually changed attitudes, preferences, and key behaviors in ways that will persist far longer than we hope that the 
virus will. Once the pandemic passes, will things return to "normal"? Or will society arrive at a "new normal" with significant changes in areas such as teleworking, transit usage, and air travel? If a "new normal" does develop, it is important for decisionmakers to be aware of it as soon as possible, so that long-range planning can accommodate these changes.

Our survey represents an important early step. The present study contributes to the literature with a focus on the potential for the pandemic experience to lead to long-term shifts in how we conduct our everyday lives, and the role of attitudes in shaping these behavioral responses. While others have looked into short-term impacts and initial consequences of the pandemic, this manuscript uniquely compares the behaviors in three points of time: before, during, and after COVID.

We conducted a survey to understand how people in the US are reacting to the pandemic, whether they expect these reactions to persist into the future, and why. For instance, do people who did not or could not telework before the pandemic expect to continue to telework once the danger has passed? Do people appreciate the convenience of online shopping for groceries, or are they chomping at the bit to return to in-person shopping as soon as it is safe to do so? We deployed the survey online, and received 1595 responses.

\section{Methods}

Our survey was developed and tested in March and April 2020 with input from researchers at many institutions, and pretested, coded, and launched within 3 weeks. Data collection began on 13 April 2020 and concluded on 20 June 2020; a follow-on data collection with a nationally representative sample is ongoing (for more information, see https://covidfuture.org). The target population is and was adults (18 and over) living in the United States. Our study received human subjects approval from the Arizona State University Institutional Review Board.

The survey covers topics including work, daily travel, air travel, shopping and dining, and attitudes and preferences. Most questions about behavior were asked three times with only minor changes: once to recall behavior before the pandemic, once to understand behavior now, and once to understand respondents' expectations for the future. This last time period is crucial, as it allows us to begin to understand how behavioral changes might persist once the pandemic has passed.

The survey was deployed online using the Qualtrics survey platform. Respondents were recruited in two ways. Most of the respondents came from a convenience sample recruited through the research team's professional and personal connections. Other respondents were recruited through Facebook advertisements, which were targeted more broadly. The project was also featured in the news media, and some respondents heard about the survey there. The breakdown of how respondents heard about the survey is shown in Figure 1.

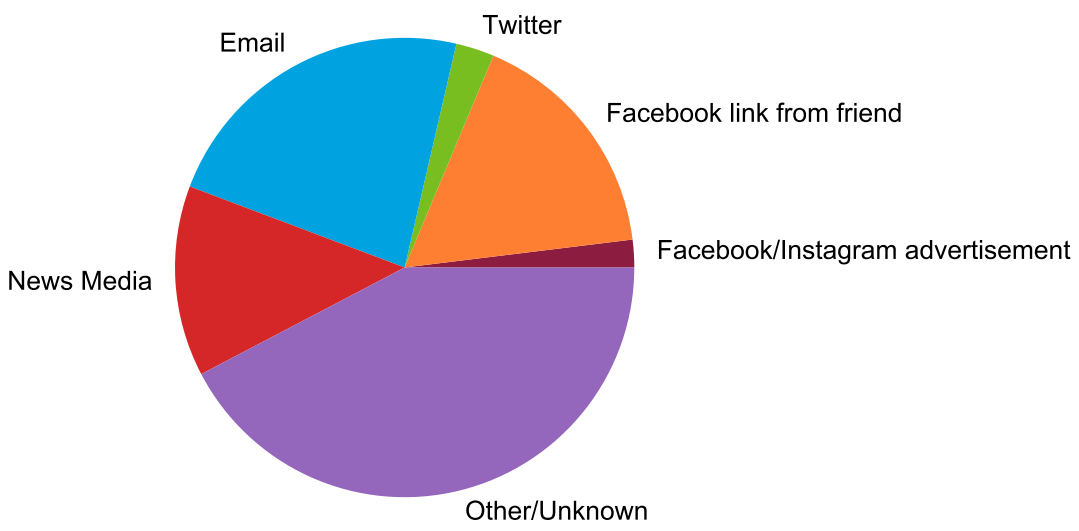

Figure 1. Where respondents heard about the survey.

Defining when the pandemic is over is important in order to get reliable information about how people expect their behavior to change. Rather than define a specific time period for respondents 
to consider, we asked that they respond to future questions for a time period "when the virus is no longer a threat". While this will be different for different people-some may no longer see it as a threat once caseloads have reduced significantly, while others may see it as a threat until a vaccine is available-this perception of risk is what will drive people's behavior, and this specification allows us to understand long-term equilibrium expectations.

As with any survey, some respondents did not answer every question. Additionally, some respondents completed only part of the survey before exiting. Since respondents who did not answer questions may not be randomly distributed, we did not want to exclude all respondents who missed any question. Instead, we excluded the respondents who did not answer a particular question when analyzing the results of that question. When analyzing attitudinal statements, we imputed the missing values. We included participants who did not complete the survey in our analyses, as long as they had made it to the part of the survey being analyzed. For this reason, most analyses in this paper do not consider the full sample size of 1595, due to deletion of records with missing data. Sample sizes for each analysis are presented with the analyses.

\section{Results}

\subsection{The Sample}

The sample analyzed here strongly over-represents highly-educated, high-income households. Table 1 compares the survey results with a number of demographic indicators from the US Census American Community Survey.

While only $13 \%$ of Americans have graduate degrees, 59\% of our respondents do. Individuals with bachelor's degrees are overrepresented as well, although not to the same extent, while individuals without a four-year college education are dramatically underrepresented. This is not surprising, given how the survey was distributed; many of the people in the professional and personal networks of the research team are academic researchers themselves. Likely as a consequence of this overrepresentation of highly-educated individuals, respondents to our survey also have higher household incomes than the general population.

The sample is more representative in terms of age and gender. Adults over 65 are underrepresented, as are young adults aged 18-24. Other age groups are represented more accurately. Women are slightly overrepresented in the sample. Racially and ethnically, the sample underrepresents African-Americans and Hispanics, and overrepresents whites and Asians.

Survey respondents came from 46 states and the District of Columbia, with the least representation from rural states (Figure 2). Arizona is overrepresented since it is where the research team is based, and thus many respondents from their networks live there. People in denser areas are overrepresented relative to people in low-density and rural areas (Table 1). Survey respondents are also more likely to commute by transit, cycling, walking, or working at home than the general population.

Due to the small number of respondents in some categories-especially lower income and educational attainment-we did not feel that weighting the data would provide meaningful results. When there are only a few respondents in a particular category, weighting them to be representative amplifies any random error in their responses. Thus, the results presented herein are unweighted, and represent the behaviors, attitudes, and expectations of a largely highly educated, high income group of people.

Most of our analysis identifies changes in behavior over time for the same people. Thus, even though our sample does not represent the population, our analyses of trends are internally consistent. We do not compare the future behaviors of our sample with current behaviors in the overall population. For instance, we compare the level of expected future working from home in our sample to pre-pandemic levels in our sample, rather than to those reported in the census. 
Table 1. Demographics of survey respondents, relative to census totals (from 2018 1-year American Community Survey, density from 2014-2018 5-year American Community Survey).

\begin{tabular}{|c|c|c|c|}
\hline & & Survey & Census \\
\hline \multirow{6}{*}{$\begin{array}{l}\text { Education } \\
\text { respondents } 25 \text { years } \\
\text { old or older } \\
(n=1163)\end{array}$} & No school completed & - & $1.5 \%$ \\
\hline & Some grade/high school & $0.3 \%$ & $10.2 \%$ \\
\hline & Completed high school or GED & $0.4 \%$ & $26.9 \%$ \\
\hline & Some college or technical school & $7.1 \%$ & $28.9 \%$ \\
\hline & Bachelor's degree(s) or some graduate school & $33.2 \%$ & $20.0 \%$ \\
\hline & Completed graduate degree(s) & $59.1 \%$ & $12.6 \%$ \\
\hline \multirow{11}{*}{$\begin{array}{l}\text { Income } \\
(n=1196)\end{array}$} & Less than $\$ 10,000$ & $1.9 \%$ & $6.3 \%$ \\
\hline & $\$ 10,000$ to $\$ 14,999$ & $1.1 \%$ & $4.3 \%$ \\
\hline & $\$ 15,000$ to $\$ 24,999$ & $2.5 \%$ & $9.0 \%$ \\
\hline & $\$ 25,000$ to $\$ 34,999$ & $2.9 \%$ & $8.9 \%$ \\
\hline & $\$ 35,000$ to $\$ 49,999$ & $5.8 \%$ & $12.4 \%$ \\
\hline & $\$ 50,000$ to $\$ 74,999$ & $14.2 \%$ & $17.4 \%$ \\
\hline & $\$ 75,000$ to $\$ 99,999$ & $12.7 \%$ & $12.6 \%$ \\
\hline & $\$ 100,000$ to $\$ 124,999$ & $14.5 \%$ & $9.2 \%$ \\
\hline & $\$ 125,000$ to $\$ 149,999$ & $12.5 \%$ & $5.8 \%$ \\
\hline & $\$ 150,000$ to $\$ 199,999$ & $11.1 \%$ & $6.6 \%$ \\
\hline & $\$ 200,000$ or more & $20.8 \%$ & $7.6 \%$ \\
\hline \multirow{5}{*}{$\begin{array}{l}\text { Age } \\
(n=1196)\end{array}$} & $18-24$ & $6.1 \%$ & $12.1 \%$ \\
\hline & $25-34$ & $27.9 \%$ & $17.9 \%$ \\
\hline & $35-49$ & $32.3 \%$ & $24.5 \%$ \\
\hline & $50-64$ & $25.7 \%$ & $24.9 \%$ \\
\hline & 65 and over & $8.0 \%$ & $20.7 \%$ \\
\hline \multirow{3}{*}{$\begin{array}{l}\text { Gender } \\
(n=1234)\end{array}$} & Female & $58.1 \%$ & $50.8 \%$ \\
\hline & Male & $41.4 \%$ & $49.2 \%$ \\
\hline & Other & $0.5 \%$ & - \\
\hline \multirow{6}{*}{$\begin{array}{l}\text { Race and Ethnicity } \\
(n=1197)\end{array}$} & Non-Hispanic White & $78.4 \%$ & $60.2 \%$ \\
\hline & Non-Hispanic Asian & $8.1 \%$ & $5.6 \%$ \\
\hline & Non-Hispanic Black/African American & $1.8 \%$ & $12.3 \%$ \\
\hline & Other non-Hispanic & $1.6 \%$ & $1.1 \%$ \\
\hline & Two or more races, non-Hispanic & $3.3 \%$ & $2.5 \%$ \\
\hline & Hispanic or Latino & $6.8 \%$ & $18.3 \%$ \\
\hline \multirow{5}{*}{$\begin{array}{l}\text { Density } \\
\text { persons } / \mathrm{km}^{2} \\
\text { in ZIP code } \\
(n=1198)\end{array}$} & 100 or less & $6.3 \%$ & $24.7 \%$ \\
\hline & $100-500$ & $15.0 \%$ & $23.9 \%$ \\
\hline & 500-1000 & $9.3 \%$ & $14.5 \%$ \\
\hline & $1000-2000$ & $30.3 \%$ & $18.5 \%$ \\
\hline & More than 2000 & $39.1 \%$ & $18.4 \%$ \\
\hline \multirow{6}{*}{$\begin{array}{l}\text { Commute mode } \\
\text { to work } \\
\text { pre-pandemic } \\
(n=1091)\end{array}$} & Drive alone & $49.6 \%$ & $76.3 \%$ \\
\hline & Carpool & $4.1 \%$ & $9.0 \%$ \\
\hline & Public transport & $23.0 \%$ & $4.9 \%$ \\
\hline & Walk & $5.3 \%$ & $2.6 \%$ \\
\hline & Bicycle or other & $11.9 \%$ & $1.9 \%$ \\
\hline & Worked at home & $6.0 \%$ & $5.3 \%$ \\
\hline Sample size & & 1595 & \\
\hline
\end{tabular}

In addition, the response of these particular groups to the COVID-19 pandemic is perhaps especially important to understand. They are frequent restaurant patrons and travelers, are likely to have the option to telecommute during the pandemic, and tend to live in larger US cities. Individuals in our sample frequently used transit and air travel before the pandemic, making changes in their travel choices of critical importance to transportation planners and the airline industry. The large proportion of white collar workers in our sample also yield insights into the effectiveness of transitions to remote work, which requires study as telecommuting becomes an increasingly prevalent response to the continuing pandemic. Higher income individuals like those in our sample dined out and shopped 
regularly pre-pandemic, meaning that their responses to the pandemic in the areas of shopping and dining are important to understand. Understanding these people's current and expected future choices helps to inform our understanding of how the nation's economy might recover, or not.

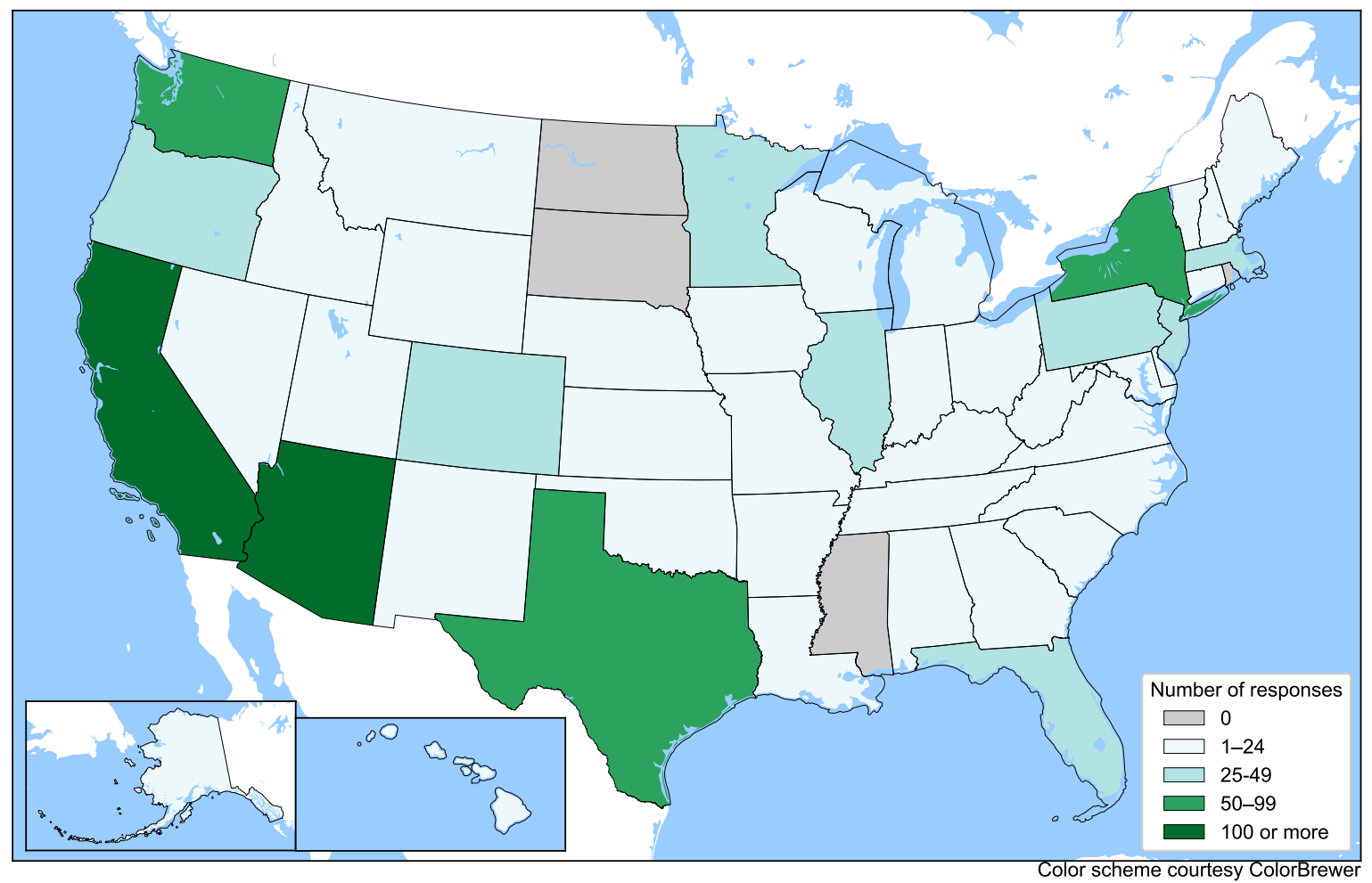

Figure 2. Number of responses by state.

Where possible, we report results separately for those sub-groups whose choices will be especially important in determining post-pandemic societal changes. For instance, these include those who are new to telecommuting and those whose pre-pandemic consumption of travel and dining services was high.

Though they have been significant, we do not address the equity implications of the pandemic because our sample is not sufficiently representative of the population.

\subsection{Pandemic Experience}

Less than $1 \%$ of respondents (of $n=1179$ ) either tested positive for COVID-19 or have a household member or roommate who tested positive. However, $16 \%$ of respondents believe they or a household member/roommate have had COVID-19, suggesting testing deficiencies at the time of the survey.

While the pandemic has indubitably caused negative impacts across society, $85 \%$ of respondents (of $n=1268$ ) to our survey responded that there were aspects of the changes they have made in response to the pandemic that they would or might like to continue after the pandemic subsides. This overwhelming fraction of respondents who are seeing some "bright side" aspects to their pandemic lifestyle suggests that the pandemic experience will have long-term effects on behavior, even once the danger has passed. We followed up with an open-ended question asking people to explain which aspects of pandemic life they are enjoying. Many mentioned spending more time with their families and enjoying a slower pace of life. Of those within this group who were also new to regularly working from home $(n=448), 59 \%$ volunteered that they would like to continue working from home at least part-time. 


\subsection{Working from Home}

Since the start of the pandemic, many workers have transitioned from in-person work to working at home. Kramer and Kramer [8] called this abrupt shift a "great work from home experiment" and expect a better understanding of the effectiveness of working from home for different groups to develop. Some researchers expect an increase in telecommuting over the next two years, including reduced concerns from employers, awareness of cost-savings, and sustainability impacts [9]. However, others have found that only $12 \%$ of U.S. workers wish to telecommute full-time, and that younger generations are less satisfied and feel less productive when working from home [10].

Among our respondents, the vast majority of workers were working from home when surveyed. Before the pandemic, roughly $45 \%$ of employed survey respondents $(n=1396)$ reported working from home at least a few times a month, and 6\% worked from home every day. Now, 90\% of full-time workers answering our survey $(n=1123)$ worked from home four or more days during the past week. Employers have clearly become much more flexible in allowing employees to work from home during a period where in-person work can pose a health risk.

Our survey data gives an early quantitative look into the post-pandemic future, and indicates that this trend of working from home is likely to continue. Figure 3 summarizes how remote work has changed in light of the pandemic and how respondents expect to work in the future. The sizes of the bars represent the percentage of respondents in each category, and the thickness of the lines indicates how many respondents in a particular category in one time period were in a corresponding category in the next time period. The color of the lines corresponds to the answers in the pre-pandemic time period. "Working from home" is defined as at least a few remote workdays per month.

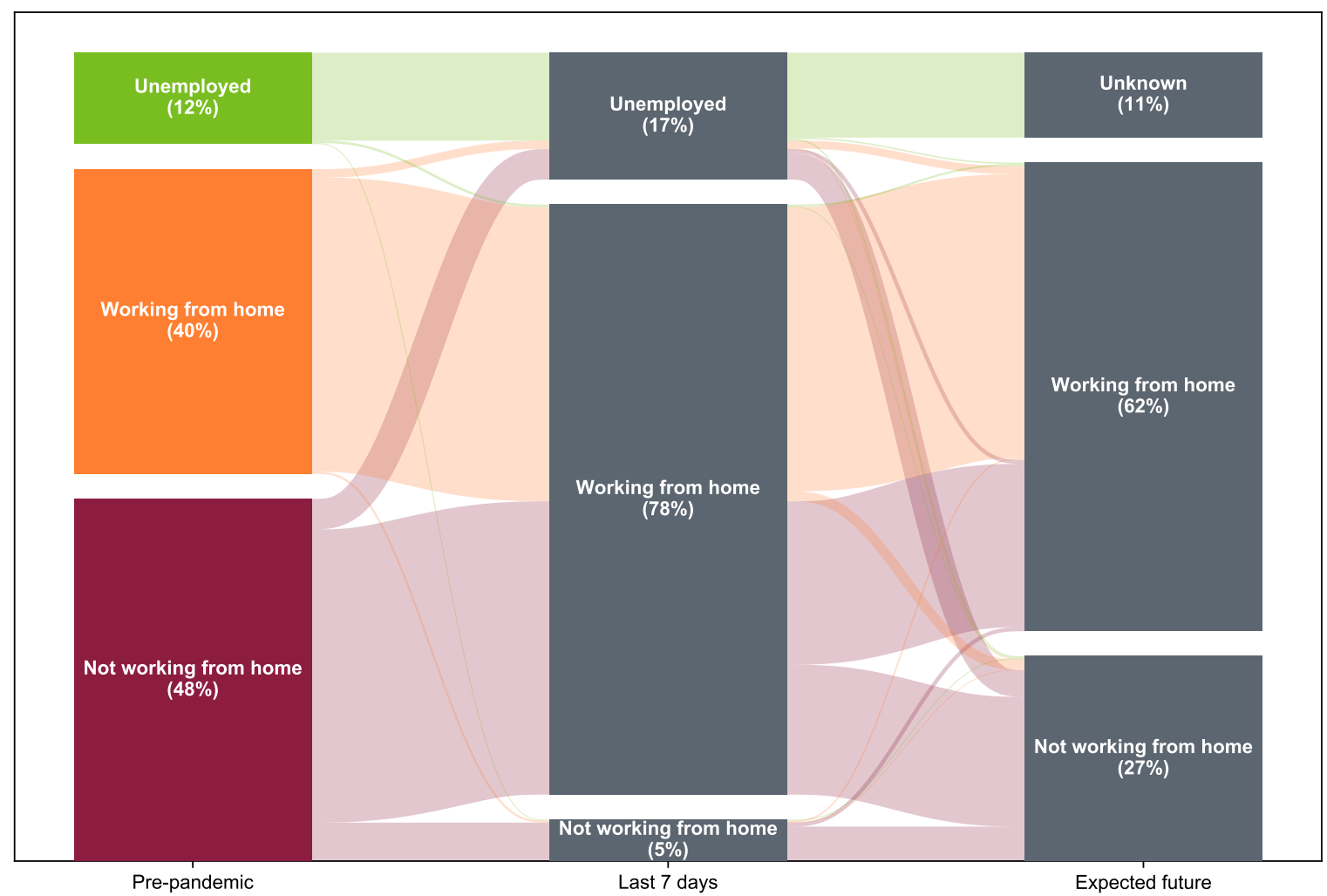

Figure 3. Trends in working from home at least a few times a month before, during, and after the pandemic $(n=1518)$.

Importantly, respondents were only able to specify that they expected to work from home post-pandemic if they expected that their employer would allow or continue to allow working from home. This means that the responses to this question reflect both employee preference as well as 
expected employer policies. Since many employers have already communicated or discussed expected policies, we expect that these perceptions are relatively accurate. They are also consistent with survey results from employers in Massachusetts, who expect a significant increase in working from home even after a vaccine is available [11].

About half of the people who were not working from home before the pandemic, but are now, expect to continue working from home at least a few times a month once the pandemic subsides. This translates to a significant increase in the proportion of respondents working from home at least part of the time-from $40 \%$ before to over $60 \%$ after the pandemic. Furthermore, among respondents who were already working from home at least a few times a month before the pandemic $(n=610)$, $36 \%$ expect to work from home more often than they did before the pandemic.

However, a complete or near-complete shift to telecommuting is unlikely. Among the 350 respondents who did not work from home at least a few times a month before the pandemic, and do expect to do so after, most do not want to be fully remote workers; about $40 \%$ of them want to telecommute a few times per week, and 55\% only want to work from home a few times per month. Only 5\% expect to work from home every day. Since full-time telecommuting seems unpopular, it is unlikely that the pandemic will induce firms to completely abandon their office spaces, or for workers to leave metropolitan areas. However, if a significant portion of office workers do start to work from home some of the time, there could be significant impacts on peak-hour travel demand and the demand for services in business districts.

Whether employers will continue to offer the option for remote work in a post-pandemic world depends critically on remote worker productivity. Among people who have started working from home since the pandemic began, 36\% have experienced a decrease in their productivity, $20 \%$ have experienced an increase, $19 \%$ report no change, and the remaining $25 \%$ have experienced both increases and decreases in their productivity $(n=539$; this analysis excludes 55 respondents who had the option to work from home but never did before the pandemic).

We asked respondents about the reasons for their change in productivity, which are shown in Table 2. Among those reporting an increase in at least some aspect of their productivity, 79\% report that the lack of time spent commuting is a contributor.

Table 2. Reasons for a change in productivity among those who started working from home.

\begin{tabular}{lc}
\hline Reasons for Increased Productivity $\left(n=237^{\dagger}\right)$ & \\
\hline No commuting time & $79.3 \%$ \\
Less distractions at home & $45.6 \%$ \\
My job is demanding more of me & $36.3 \%$ \\
More comfortable workspace at home & $32.1 \%$ \\
In crisis situations, I'm able to focus better & $20.3 \%$ \\
\hline Reasons for Decreased Productivity $\left(n=321^{\dagger}\right)$ & \\
\hline More distractions at home & $55.1 \%$ \\
There are too many concerns on my mind to be able to focus fully on work & $52.0 \%$ \\
Difficult to communicate with co-workers & $42.7 \%$ \\
Lack of comfortable workspace & $39.3 \%$ \\
Need equipment or technology not available at home & $24.0 \%$ \\
Have to share workspace with another worker & $16.8 \%$ \\
Childcare & $15.9 \%$ \\
Elder/other dependent care & $2.2 \%$ \\
Need to care for sick household member & $1.2 \%$ \\
\hline t Respondents could choose “In some way [my productivity] has decreased and in other \\
ways it has increased" and thus be asked questions about reasons for both decreased and \\
increased productivity.
\end{tabular}


Predictably, remote worker productivity depends on the home and work environments. Distractions at work cause increased productivity at home. Distractions at home lead to decreased productivity at home.

One of the most oft-cited reasons for a decrease in productivity is "[t]here are too many concerns on my mind to be able to be able to focus fully on work". Unlike a reduction in commuting time, this is a temporary change due to the pandemic - suggesting that the productivity implications of a long-term shift towards working from home might be more positive than shown in this survey.

Whether these expectations regarding working from home come to fruition remains to be seen. Scholars have been forecasting a "death of geography" for decades, brought about by improved information and communications technologies (e.g., [12]). However, despite such predictions, cities have continued to grow. Sassen [13] argues that these technologies have actually played a role in concentration in cities, because even as they allow communication over long distances, they increase demand for command and control functions to administer vast global enterprises. Sassen argues that these functions can only be served by face-to-face interaction. Perhaps technology and workers' experience with that technology has advanced to a point where this is no longer true, or perhaps once the danger is forgotten people will return to the benefits of in-person collaboration.

\subsection{Shopping, Dining, and Deliveries}

Another area that is seeing large shifts in behavior during the pandemic is shopping and restaurant patronage. Results from an early stated preference study suggest that preferences for in-person grocery shopping are related to the number of COVID-19 cases in the region, suggesting that in-person shopping may drop where virus spread is increasing [14]. Survey data collected in Chicago revealed that online grocery shopping and online ordering of prepared meals increased significantly in the first two months of the pandemic [3]. Data from the restaurant industry indicate that both fine dining and fast food chains were severely affected by the pandemic, with most businesses operating at less than $20 \%$ capacity during early months of the pandemic [15]. While the long-term effects of such changes are still unclear, research indicates that the trends toward online shopping and away from in-person dining are likely to outlive the pandemic [3].

In our survey, we asked about three distinct types of online purchases: groceries, non-groceries, and restaurant takeout and delivery. The pandemic has caused online shopping to become more popular, while restaurant patronage is significantly down. Our survey data indicates that these changes are likely to persist at least somewhat.

Restaurant takeout and delivery has increased the most in popularity during the pandemic; nearly $70 \%$ of respondents $(n=1334)$ ordered from restaurants in the past week, while only $54 \%$ of respondents got takeout at least a few times per month before COVID-19. Online shopping for groceries was somewhat uncommon before the pandemic (only $23 \%$ of respondents ever used online grocery shopping services), but has become more prevalent, with nearly a third of respondents $(n=1346)$ purchasing groceries online in the past week. In contrast, online shopping for non-groceries was very popular before the virus outbreak, with $70 \%$ making purchases multiple times per month $(n=1357)$. During the pandemic, $77 \%$ of respondents shopped online for non-groceries in the past week.

The outlook for total restaurant patronage, including dine-in service, is not rosy. Pre-pandemic, the fraction of respondents who patronized restaurants at least a few times a month in any form was over $90 \%$ (of $n=1334$ ). During the pandemic, the fraction patronizing restaurants at all in the last week has dipped to $70 \%$-almost all via takeout and delivery. Looking to the future, nearly $40 \%$ of people who dined in at least a few times a month $(n=1178)$ plan to dine in less often and only about $40 \%$ of these 450 people plan to substitute takeout or restaurant delivery. Taken together, this means that about a quarter of people who used to regularly dine at restaurants expect to reduce their restaurant patronage for the long term. If these expectations are accurate, the restaurant industry, which employed more than 12 million people in the US at the end of 2019 [16], will be severely impacted. 
Online purchasing will likely maintain some of the popularity it has gained during COVID-19, according to our survey respondents. For both groceries $(n=1346)$ and non-grocery items $(n=1357)$, about $20 \%$ of respondents expect a long term increase in use of these services. Three-quarters of our respondents had never shopped online for groceries, whereas approximately this fraction regularly shopped online for non-grocery items. An increase from never may still indicate a low-frequency of online grocery shopping, whereas an increase from a baseline of already frequent use may translate into many more non-grocery online shopping events. About $10 \%$ expect a decrease in use of online purchasing, though a majority of those reporting decreased online grocery shopping never used these services pre-pandemic, suggesting they misinterpreted the question as being relative to current behavior.

\subsection{Daily Travel}

During the pandemic, particularly in the early days when this survey was conducted, travel was down drastically; over $40 \%$ of respondents did not report any trips on at least five of the last seven days $(n=1301)$. After the pandemic, it is not clear if daily travel patterns will be the same as they were before. We asked respondents how they expect their transport mode choices to change once the danger from the pandemic has passed, relative to their usage before the pandemic. While most respondents expected their use of various modes to stay the same, a significant minority of respondents indicated that they expect a change (Figure 4).

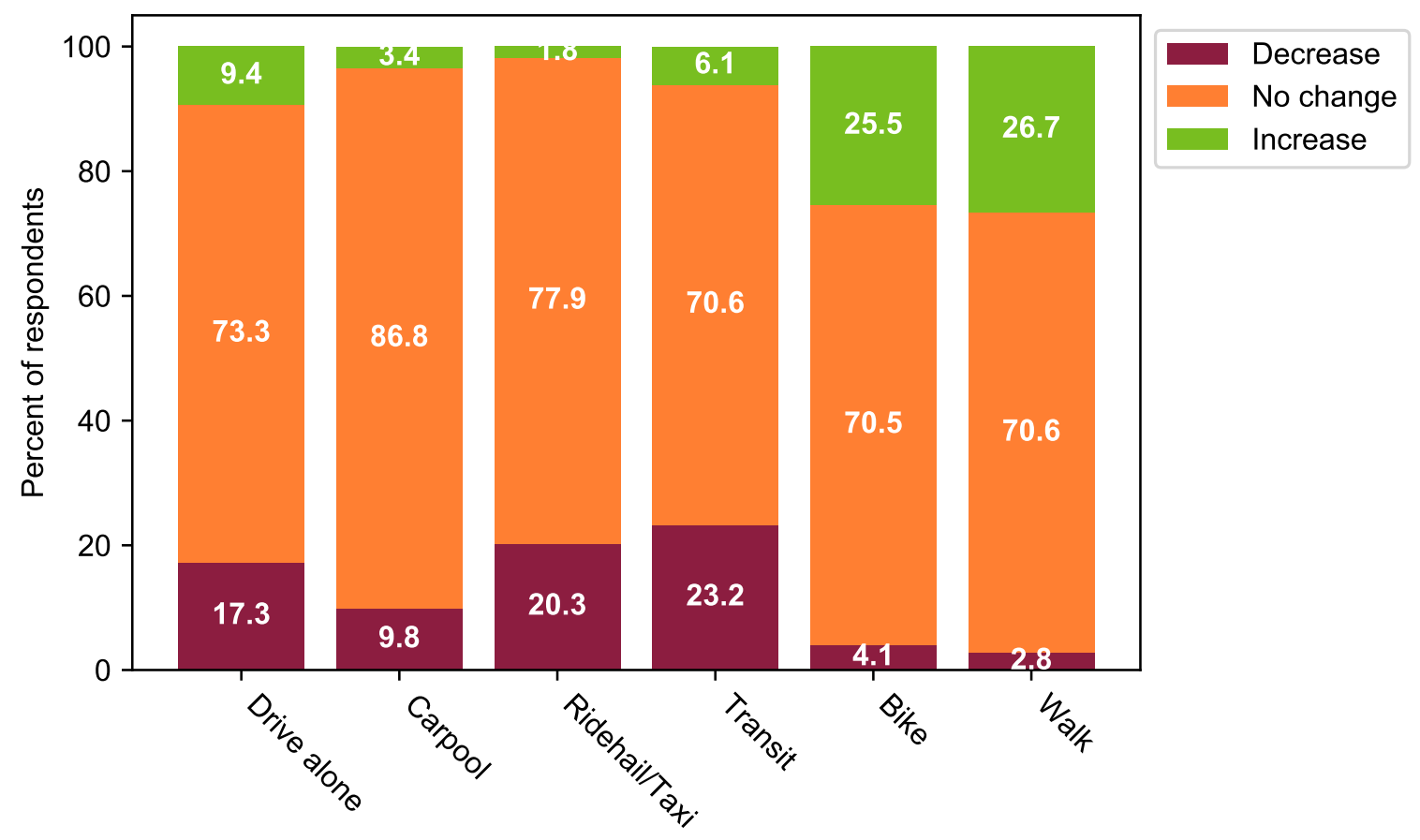

Figure 4. Expected change in mode usage $(n=1308)$.

There is a clear division between the modes. About $20 \%$ of respondents expect to use transit and ridehailing less than they did before the pandemic, while about $25 \%$ expect to see an increase in their walking and biking. The story for driving is more mixed: $17 \%$ expect a decrease in their driving alone, while $9 \%$ expect an increase. Other forms of driving such as carpooling are also expected to decrease. These changes in driving are at least partly driven by an increase in working from home; respondents who did not work from home at least a few times a month before the pandemic and expect to afterwards $(n=312)$ are 2.1 times more likely to report a decrease in driving than workers who did not work from home at least a few times a month before the pandemic and do not expect to do so afterwards $(n=323)$. 
A decrease in transit usage is of particular concern for policymakers, as it would compound existing trends towards lower transit usage [17]. This concern is particularly salient if those who expect to reduce their transit usage transition to driving, with the concomitant congestion and greenhouse gas impacts that implies. Table 3 examines this by providing the percentage of respondents who reported an expected decrease in each mode that also reported an expected increase in another mode. Looking at the "Transit" row in the table, we see that among the 304 respondents who reported an expected decrease in transit use, $23.0 \%$ expect an increase in driving alone, 3.9\% expect to increase carpooling, $2.6 \%$ expect to increase ridehail use, and a whopping $42.4 \%$ and $43.8 \%$ expect to increase their biking and walking, respectively. At least among these respondents, then, the effect of a reduction in transit use will be mixed-while many transit users expect to shift to driving, a larger fraction expect to shift to biking and walking.

Table 3. Percent of respondents expecting a decrease in one mode who also expect an increase in another mode.

\begin{tabular}{|c|c|c|c|c|c|c|c|c|}
\hline & & \multicolumn{4}{|c|}{ Increase in... } & \multirow[b]{2}{*}{ Bike } & \multirow[b]{2}{*}{ Walk } & \multirow[b]{2}{*}{$n$} \\
\hline & & Drive Alone & Carpool & Ridehail/Taxi & Transit & & & \\
\hline \multirow{6}{*}{ Decrease in... } & Drive alone & & $7.1 \%$ & $1.3 \%$ & $11.9 \%$ & $41.2 \%$ & $42.5 \%$ & 226 \\
\hline & Carpool & $25.8 \%$ & & $0.8 \%$ & $4.7 \%$ & $36.7 \%$ & $44.5 \%$ & 128 \\
\hline & Ridehail/Taxi & $19.6 \%$ & $4.2 \%$ & & $6.4 \%$ & $41.9 \%$ & $48.7 \%$ & 265 \\
\hline & Transit & $23.0 \%$ & $3.9 \%$ & $2.6 \%$ & & $42.4 \%$ & $43.8 \%$ & 304 \\
\hline & Bike & $18.9 \%$ & $0.0 \%$ & $0.0 \%$ & $7.5 \%$ & & $17.0 \%$ & 53 \\
\hline & Walk & $19.4 \%$ & $5.6 \%$ & $0.0 \%$ & $2.8 \%$ & $11.1 \%$ & & 36 \\
\hline
\end{tabular}

From the perspective of the transit agency, however, our data are less promising. Among those who used transit at least a few times each week pre-pandemic $(n=395)$, over $40 \%$ expect to decrease their transit use. Such a decrease will hit already-struggling transit agencies hard; they may be forced to cut service as fare revenue declines. Some major transit agencies are already facing the prospect of significantly curtailed or discontinued service [18]. Maintaining transit service will likely require additional public subsidy in the wake of the pandemic.

It is likely that a widespread transition to remote work will be a driver of lower transit ridership. Expected transit ridership in the future is correlated with working from home. People transitioning from in-person to remote work at least a few times a month $(n=312)$ are 2.8 times as likely to report expected decreases in transit use as workers remaining in-person $(n=323)$. If the lost riders are primarily peak-period commuters, the ridership loss may be less significant to transit agencies from a fiscal standpoint, as peak-period trips are relatively expensive trips to serve [19], but any ridership decline could lead to service cuts which in turn lead to additional ridership decline and an undermining of public support for transit.

The large fraction of respondents who expect to increase their biking and walking is remarkably consistent for all those who expect to decrease their use of other modes. Of particular interest is the additional fact that nearly half of those who expect to increase their bicycle use $(n=335)$ were not previously regular bicyclists. This particular finding may be either a temporary effect of pandemic living or a finding that is specific to our sample and not necessarily representative of the US adult population. If this result remains robust in our future data collection efforts, however, it is important for transport planners and policymakers to consider in planning for the post-pandemic future.

From a climate, pollution, and public health standpoint, an increase in biking and walking is highly desirable. However, walking and biking are unsafe in much of the US [20,21]. During the pandemic, many cities have created temporary spaces for cycling and walking by closing or restricting streets to auto traffic [22], and some have made certain street closures permanent (e.g., [23]). For a long-term increase in walking and cycling to materialize, cities will need to engage in focused planning and make substantial investments in safer pedestrian and bicycle infrastructure. A reduction in 
peak-hour travel demand due to increased working from home makes now an ideal time to reallocate road space to pedestrians and cyclists while avoiding many congestion impacts.

\subsection{Air Travel}

Air travel has seen particularly large reductions during the pandemic. US air passenger numbers were down 95\% year-over-year in April 2020 when we began data collection ([24], and author calculations), with up to two-thirds of the world's fleet being grounded at least temporarily [25]. While air travel has recovered somewhat, domestic air flights of U.S. airlines were still down $67 \%$ compared to 2019 levels in September 2020, and international travel through U.S. airlines was 83\% below 2019 traffic, with many airlines being forced into reducing or stopping operations entirely across the globe [26]. If these changes persist beyond the pandemic, even in limited form, the airline industry could undergo significant economic damage. There could also be environmental benefits, given that aviation is a significant contributor to environmental degradation.

The respondents to this survey $(n=1299)$ were heavy users of air travel before the pandemic began, with $95 \%$ flying at least once a year, and $64 \%$ flying a few times a year or more. While the majority of travelers said they expected their use of air travel to remain about the same after the pandemic, $35 \%$ of those who reported personal air travel at least once a year $(n=1236)$, and $50 \%$ of those who reported business air travel at least once a year $(n=745)$, expected to reduce their air travel once the pandemic subsides. These expectations indicate that the decrease in flying will be "sticky", or likely to persist after the pandemic. Frequent air travelers were more likely to report an expected decrease in air travel, relative to infrequent air travelers (Figure 5).
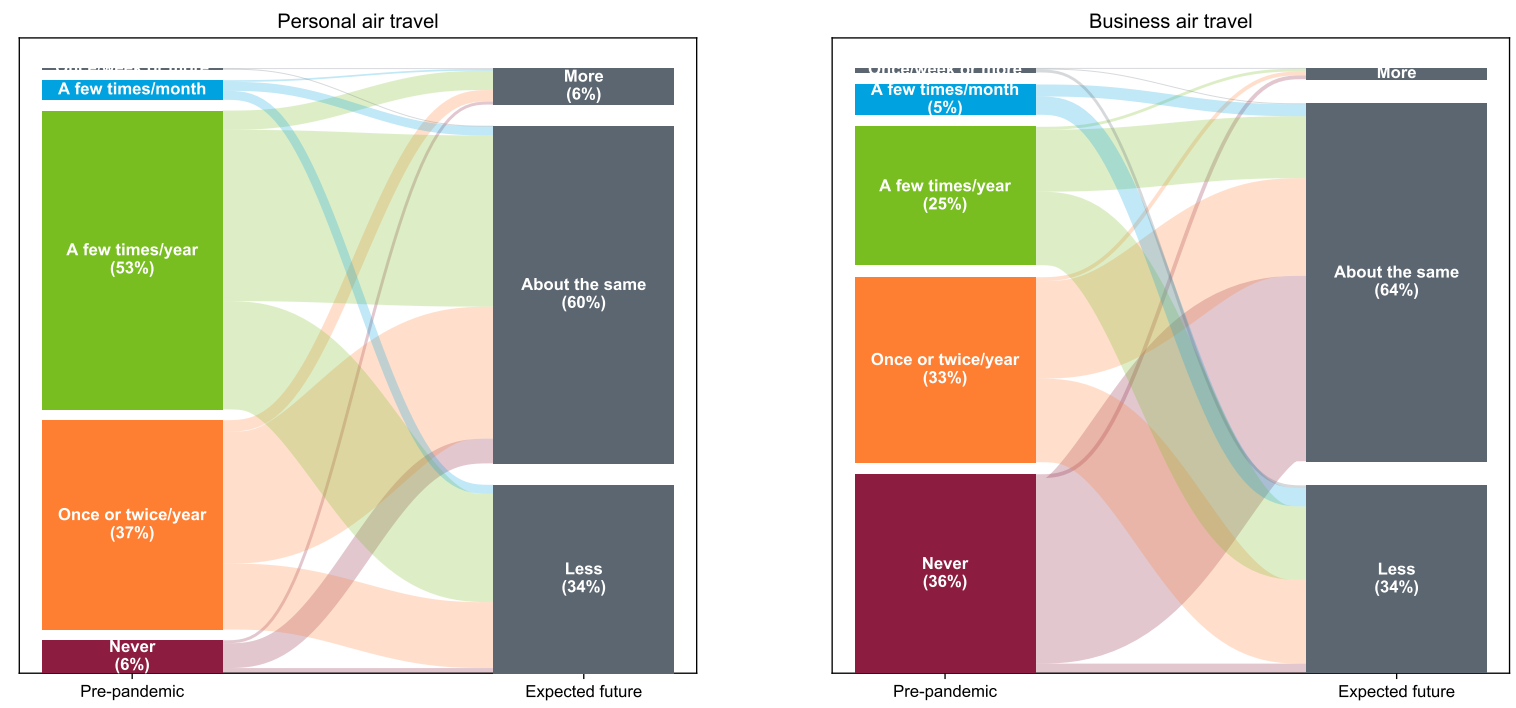

Figure 5. Expected change in personal and business air travel after the pandemic, relative to before. Business air travel is only for individuals who reported working before or during the pandemic $(n=1159)$, while personal is for all respondents who answered the question $(n=1313)$.

We also asked respondents to select the reason they anticipate changes in their air travel. This question revealed some important differences between those who fly for business reasons and those who fly for personal reasons (Table 4). The majority of personal travelers expecting a change in their air travel reported that they did not feel safe sharing space with others, a concern that is likely to be confined to the short term if the virus can be brought under control. However, business travelers reported structural changes in their reasons for travel, with a majority of business travelers expecting to reduce their air travel citing increased reliance on electronic communications. Concerns over sharing space with strangers were only cited by $27 \%$ of business travelers expecting to reduce their air travel. 
About $22 \%$ of business travelers anticipating a reduction in air travel also indicated that their companies had committed to reduce air travel. Depending on whether this change was in response to the virus or in response to environmental concerns predating COVID-19, this change may or may not persist past the pandemic.

A long-term reduction in business travel could have a significant impact on airline revenues. For example, in 2019, 41\% of Delta Air Lines' ticket revenue came from business and first-class tickets ([27], p. 31 and author calculations), likely primarily purchased by business travelers, and many business travelers of course also purchase economy-class tickets. A reduction in travel by this lucrative passenger segment could have outsize impacts on on airline revenue. This drop in passenger demand will likely cause a reduction in service, as airlines adjust their route networks to match demand, which may lead to a reduction in personal travel as well. Airlines may also be forced to raise prices due to diminishing economies of scale, causing a similar drop in demand for price-sensitive personal travelers.

Table 4. Percent of respondents reporting a change in their air travel selecting particular reasons for that change.

\begin{tabular}{lc}
\hline Reasons for an Increase in Business Air Travel $(n=21)$ & $42.9 \%$ \\
\hline I want/need to take trips that were cancelled during the COVID-19 pandemic & $42.9 \%$ \\
\hline My job changed and I now have more need to travel by airplane & $51.5 \%$ \\
\hline Reasons for a Reduction in Business Air Travel $(n=388)$ & $31.4 \%$ \\
\hline Those I meet with have realized that we can conduct meetings by conference call/video conference & $26.8 \%$ \\
I realized I could conduct my meetings by conference call/video conference & $22.4 \%$ \\
I don't feel safe or comfortable sharing close space with strangers & $8.0 \%$ \\
My company adopted a commitment to reduce travel by airplane & $7.0 \%$ \\
My job changed and I no longer need to travel by airplane & $2.8 \%$ \\
\hline I anticipate taking more of my long-distance trips by car & $67.5 \%$ \\
I anticipate taking more of my long-distance trips by train or bus & $57.8 \%$ \\
\hline Reasons for an Increase in Personal Air Travel $(n=83)$ & $14.5 \%$ \\
\hline After having been cooped up at home for so long, I want to travel more than I did before & $3.6 \%$ \\
I will need/want to take trips that were cancelled during the COVID-19 pandemic & $65.5 \%$ \\
My financial circumstances changed and I can now afford more air travel & $39.8 \%$ \\
My priorities changed and I no longer want to or can travel in the same way & $31.9 \%$ \\
\hline Reasons for a Reduction in Personal Air Travel $(n=432)$ & $14.8 \%$ \\
\hline I don't feel safe or comfortable sharing close space with strangers & $12.3 \%$ \\
I anticipate taking more of my long-distance trips by car & $12.0 \%$ \\
My priorities changed and I no longer want to or can travel in the same way & \\
My financial circumstances changed and I can no longer afford to travel in the same way & I anticipate taking more of my long-distance trips by train or bus \\
I am able to use technology (e.g., FaceTime, Zoom) to meaningfully engage with long-distance connections & $1.5 \%$ \\
\hline
\end{tabular}

A small number of business and personal travelers expect an increase in air travel after the pandemic, many of whom anticipate needing to take trips canceled due to COVID-19. Personal travelers also express a desire to travel after being stuck at home. Both of these trends are likely to be temporary.

Overall, it seems that the pandemic is likely to have lasting effects on air travel, with Americans flying less than they did before the pandemic, especially for business.

\subsection{Students}

One important result of COVID-19 has been a change in the college student experience. The pandemic has made traditional in-person learning unsafe, forcing students and educators alike to make use of online classes or other alternatives. Data from our sample of students reveals important information about how the pandemic has affected students and how they hope to learn in the future. 
As a result of universities' response to COVID-19, students have delayed graduation, missed job opportunities, and an estimated $29 \%$ expect decreased earnings by the age of 35 [28].

Universities have varied somewhat in their response to the pandemic, though moving in-person classes online was the most common strategy reported by respondents. In total, $13 \%$ of students were not taking classes at the time and were unaffected by university policies during the pandemic. Around $67 \%$ of students $(n=262)$ reported that their classes transitioned partially or completely online (an additional 10\% were already fully online students). Meanwhile, $6 \%$ reported that all or some of their classes had been canceled.

Our survey indicates that policy changes from universities have largely been to the detriment of student learning. In total, $56 \%$ of students reported a worsened learning experience, $38 \%$ reported either no change or mixed effects, and the remaining $6 \%$ reported improvement $(n=173)$. One predictor of how students responded to changes in their classes was whether or not they had taken online classes before. $8 \%$ of students who had taken online classes $(n=121)$ reported improved learning. However, improved learning was not reported by any students who had not previously taken online classes $(n=52)$. These findings are in contrast with those of Aucejo et al. [28], who found that the pandemic had diverse impacts on students, with similar shares reporting increased and decreased time spent learning.

Students $(n=157)$ were also asked why the quality of their learning had decreased or increased (see Table 5). The most common reason for improved quality of learning was the absence of commuting time, with access to a more comfortable home workplace also being a major contributor to improvement. The most common reasons for decreased quality in learning were boredom while attending virtual classes, at-home distractions, and communication difficulties with professors and other students.

Table 5. Percent of respondents reporting a change in their quality of learning selecting particular reasons for that change.

\begin{tabular}{lc}
\hline Reasons for an Improvement in Learning Quality $(n=35)$ & \\
\hline No commuting time & $77.1 \%$ \\
More comfortable workspace at home & $48.6 \%$ \\
Decreased responsibilities at work & $14.3 \%$ \\
Fewer distractions at home & $11.4 \%$ \\
\hline Reasons for a Decrease in Learning Quality $(n=122)$ & \\
\hline Sitting in front of a computer for extended periods of time is too boring and monotonous & $77.9 \%$ \\
More distractions at home & $71.3 \%$ \\
Difficult to communicate with other students & $69.7 \%$ \\
Difficult to communicate with professors & $54.9 \%$ \\
Lack of comfortable workspace & $45.1 \%$ \\
Need equipment or technology not available at home & $18.0 \%$ \\
Increased responsibilities at work & $10.7 \%$ \\
Childcare & $6.6 \%$ \\
Elder/other dependent care & $4.1 \%$ \\
Need to care for sick household member & $1.6 \%$ \\
\hline
\end{tabular}

As the fall semester begins, universities need to address the challenges of educating during a pandemic with actions informed by the successes and failures of the previous semester. Luckily, many students' major complaints regarding online learning-monotonous class formats, difficulty communicating with students and professors, and a lack of necessary technology—can be addressed by administrators and instructors.

The limitation of online classes does not bar universities from providing a high-quality education. The more positive learning experience enjoyed by those who had previously taken online classes implies that it was partially the sudden change to an unfamiliar format, rather than solely the online format itself, that caused dissatisfaction among students. Engaging classes, improved systems for communication among students and instructors, and technology lending programs can all improve 
student learning this fall. In addition to these, the students' experiences are likely to improve as online classes become more familiar to them.

\subsection{Attitudes}

Attitudinal data are increasingly incorporated into analyses of transportation choices to better understand and predict behavior (e.g., [29-32]). Our survey included 39 Likert-scale questions to capture respondent attitudes about the pandemic itself as well as preferences about work and shopping, home location and travel, and modes of interaction. We used these data to identify attitudinal typologies among the respondents in our sample by conducting an exploratory factor analysis, and then using a clustering algorithm to assign respondents to typologies (see Appendix A). We call the resulting attitudinal typologies "suburban office lovers", "unconcerned", "urban shoppers", "videoconferencers", and "work-from-home extroverts." These attitudinal typologies are relatively uncorrelated with sociodemographics (Table A3), and thus add another dimension to help us understand behavior.

Two attributes emerge as strong predictors of expected post-pandemic behavior: concern about COVID-19 and preference for in-person interaction. The "unconcerned" are much less troubled about COVID-19 than all other typologies. "Urban shoppers" prefer in-person shopping and working, and "suburban office lovers" prefer in-person working. Table 6 reports pre- and post-pandemic choices for each attitudinal cluster regarding working from home, dining in restaurants, and online shopping for non-grocery items.

All groups have larger shares of respondents that expect to work from home when the virus is no longer a threat when compared to the frequency of working from home before the pandemic. Unsurprisingly, the "work-from-home extroverts" have the highest share of remote workers before the pandemic, as well as expected remote workers in a post-pandemic world. Most other groups experience larger increases in the share of respondents working from home at least a few times a month, however.

Formerly frequent diners expect to dine out less often than they used to, and formerly frequent online shoppers expect to shop online more than they used to. Our data suggest that the restaurant habits of the "unconcerned" - defined largely by their lack of concern about COVID-19-will be least affected by the pandemic. Meanwhile, the "urban shoppers" group, named for their preferences for in-person shopping, are least likely to increase their online shopping post-pandemic. Along with "work-from-home extroverts", they are also among the most likely to decrease it. This corroborates the finding that those with a preference for in-person activities expect to resume them once the virus subsides.

Table 7 reports expectations about non-motorized mobility choices in a post-pandemic world. Respondents were divided into those who reported using the mode at least a few times a week before the pandemic, and those who did not. A small number of respondents declared they never used a mode before the pandemic, but intend to use the mode even less after COVID-19 is no longer is a threat; these responses were removed from this analysis.

A large fraction of formerly frequent users of non-motorized modes expect to increase their use, but the differences were not pronounced between attitudinal typologies.

Among formerly infrequent non-motorized travelers, there were large differences between attitudinal typologies in the fraction expecting changes in mode use. The "urban shoppers" typology is most likely to expect to increase active travel, while the "suburban office lovers" are least likely to expect such an increase.

Similar analyses were performed for transit ridership and air travel as they both require passengers to be in close quarters with others. Since these modes are less frequently used, these statistics are reported for anyone who reported ever using the mode pre-pandemic. Overall, the "unconcerned" are least likely to reduce their transit use and personal air travel. For business air travel, "work-from-home extroverts" and "urban shoppers" are most likely to expect a decrease. 
Table 6. Expected change in work from home, shopping and dining frequencies, by attitudinal typology.

\begin{tabular}{|c|c|c|c|c|c|c|c|}
\hline & & Unconcerned & Videoconferencers & Urban Shoppers & Suburban Office Lovers & Work from Home Extroverts & Grand Total \\
\hline \multirow{2}{*}{$\begin{array}{l}\text { Work from home }{ }^{\dagger} \\
\text { before the pandemic }\end{array}$} & Yes & $30.9 \%$ & $42.8 \%$ & $46.3 \%$ & $35.9 \%$ & $60.3 \%$ & $45.3 \%$ \\
\hline & Sample size & 152 & 271 & 255 & 181 & 287 & 1146 \\
\hline \multirow{2}{*}{$\begin{array}{l}\text { Work from home }{ }^{\dagger} \\
\text { after the pandemic }\end{array}$} & Yes & $57.1 \%$ & $70.1 \%$ & $73.6 \%$ & $59.0 \%$ & $83.9 \%$ & $70.8 \%$ \\
\hline & Sample size & 154 & 274 & 254 & 183 & 286 & 1151 \\
\hline \multirow{3}{*}{$\begin{array}{l}\text { Expected dine-in } \\
\text { formerly frequent } \\
\text { restaurant diners }\end{array}$} & Less than before & $22.1 \%$ & $44.7 \%$ & $34.2 \%$ & $43.1 \%$ & $44.6 \%$ & $38.8 \%$ \\
\hline & More than before & $17.4 \%$ & $11.8 \%$ & $14.5 \%$ & $9.6 \%$ & $6.0 \%$ & $11.5 \%$ \\
\hline & Sample size & 149 & 262 & 275 & 167 & 267 & 1120 \\
\hline \multirow{2}{*}{$\begin{array}{l}\text { Expected online shopping } \\
\text { formerly frequent }{ }^{\dagger} \\
\text { online shoppers }\end{array}$} & Less than before & $3.5 \%$ & $5.6 \%$ & $9.2 \%$ & $6.3 \%$ & $9.3 \%$ & $7.1 \%$ \\
\hline & Sample size & 113 & 215 & 185 & 159 & 216 & 888 \\
\hline
\end{tabular}

Table 7. Expected change in non-motorized mode use after the pandemic, by attitudinal typology and previous use of walking and biking.

\begin{tabular}{|c|c|c|c|c|c|c|c|}
\hline & & Unconcerned & Videoconferencers & Urban Shoppers & Suburban Office Lovers & Work from Home Extroverts & Grand Total \\
\hline \multirow{3}{*}{$\begin{array}{l}\text { Expected bike use } \\
\text { formerly } \\
\text { frequent bike users }\end{array}$} & Less than before & $3.8 \%$ & $0.0 \%$ & $1.0 \%$ & $0.0 \%$ & $1.5 \%$ & $1.2 \%$ \\
\hline & More than before & $30.8 \%$ & $36.4 \%$ & $43.4 \%$ & $37.5 \%$ & $42.4 \%$ & $40.2 \%$ \\
\hline & Sample size & 26 & 44 & 99 & 16 & 66 & 251 \\
\hline \multirow{3}{*}{$\begin{array}{l}\text { Expected bike use } \\
\text { formerly not } \\
\text { frequent bike users }\end{array}$} & Less than before & $0.0 \%$ & $2.0 \%$ & $0.5 \%$ & $0.6 \%$ & $1.7 \%$ & $1.1 \%$ \\
\hline & More than before & $16.4 \%$ & $20.6 \%$ & $35.7 \%$ & $8.3 \%$ & $31.0 \%$ & $23.1 \%$ \\
\hline & Sample size & 140 & 247 & 185 & 180 & 232 & 984 \\
\hline \multirow{3}{*}{$\begin{array}{l}\text { Expected walking } \\
\text { formerly } \\
\text { frequent walkers }\end{array}$} & Less than before & $3.9 \%$ & $4.1 \%$ & $0.0 \%$ & $4.6 \%$ & $1.3 \%$ & $2.1 \%$ \\
\hline & More than before & $27.6 \%$ & $36.3 \%$ & $36.5 \%$ & $24.6 \%$ & $39.4 \%$ & $35.0 \%$ \\
\hline & Sample size & 76 & 146 & 222 & 65 & 160 & 669 \\
\hline \multirow{3}{*}{$\begin{array}{l}\text { Expected walking } \\
\text { formerly not } \\
\text { frequent walkers }\end{array}$} & Less than before & $1.1 \%$ & $1.9 \%$ & $0.0 \%$ & $0.0 \%$ & $2.1 \%$ & $1.2 \%$ \\
\hline & More than before & $20.2 \%$ & $20.4 \%$ & $33.8 \%$ & $8.2 \%$ & $19.7 \%$ & $19.1 \%$ \\
\hline & Sample size & 94 & 157 & 71 & 134 & 142 & 598 \\
\hline \multirow{3}{*}{$\begin{array}{l}\text { Expected transit use } \\
\text { formerly } \\
\text { transit users }\end{array}$} & Less than before & $19.2 \%$ & $31.2 \%$ & $32.4 \%$ & $27.1 \%$ & $33.3 \%$ & $30.2 \%$ \\
\hline & More than before & $12.1 \%$ & $8.5 \%$ & $9.0 \%$ & $6.5 \%$ & $5.9 \%$ & $8.1 \%$ \\
\hline & Sample size & 99 & 189 & 256 & 107 & 222 & 873 \\
\hline \multirow{3}{*}{$\begin{array}{l}\text { Expected personal } \\
\text { air travel } \\
\text { formerly flyers }\end{array}$} & Less than before & $26.3 \%$ & $35.4 \%$ & $35.6 \%$ & $35.3 \%$ & $36.4 \%$ & $34.5 \%$ \\
\hline & More than before & $5.8 \%$ & $6.6 \%$ & $6.6 \%$ & $7.1 \%$ & $5.1 \%$ & $6.2 \%$ \\
\hline & Sample size & 156 & 288 & 289 & 184 & 297 & 1214 \\
\hline \multirow{3}{*}{$\begin{array}{l}\text { Expected business } \\
\text { air travel } \\
\text { formerly flyers }\end{array}$} & Less than before & $43.0 \%$ & $43.8 \%$ & $54.2 \%$ & $43.0 \%$ & $55.9 \%$ & $49.7 \%$ \\
\hline & More than before & $3.2 \%$ & $2.7 \%$ & $1.7 \%$ & $3.0 \%$ & $0.9 \%$ & $2.0 \%$ \\
\hline & Sample size & 93 & 146 & 177 & 100 & 222 & 738 \\
\hline
\end{tabular}




\section{Discussion}

Thus far, we have reported findings about each transport-related topic separately. Here, we put them together to provide a holistic view of what the future may hold for real estate, traffic congestion, and the environment. The pandemic is likely to cause many changes in these areas, but in most cases the direction of the net effect depends on the relative magnitude of various competing effects, and is ambiguous.

\subsection{Real Estate}

A long-term shift to more working from home will affect the demand for commercial real estate in multiple ways. For office space, the overall effect is uncertain. Even before the pandemic, companies were reducing the amount of office space they provided to each employee, at least partly as a way to reduce costs [33]. With more employees working from home, this trend might continue. However, companies may also want to decrease density in offices to promote social distancing and to prevent the spread of future illnesses. Research has shown that open-plan offices are associated with increased sick leave [34]. Furthermore, introducing viral material into an office leads to rapid spread to many surfaces, although strict hygiene protocols can significantly reduce transmission [35]. Depending on the relative magnitude of these two trends, demand for office space could either increase or decrease.

Regardless of office space demand, our results clearly suggest that more of office workers will be working remotely at least some of the time. A reduction in the number of workers in office districts will mean reduced demand for services such as restaurants and office supply stores in these areas, reducing demand for commercial space used by retail stores and restaurants.

Residential space has shown an increasing trend, with the average size of new single-family homes in the US growing significantly since the 1950s, even as household sizes have dropped [36,37]. A shift to working from home may accelerate this trend, as workers demand homes with dedicated workspace. More time spent at home may similarly increase the demand for private yard space, accelerating an existing trend towards larger lot sizes [38].

These trends, taken together, could lead to a glut of office and commercial space and a shortage of residential space. US zoning regulations often strictly separate commercial uses and residential uses; relaxing these regulations to allow conversion of commercial space to residential use is an avenue potentially worth exploring.

\subsection{Traffic Congestion}

If nothing else changed, a widespread shift to remote work and increasing work hour flexibility could dramatically reduce peak-hour traffic congestion, even if people only work from home some of the time. Traffic congestion delays rise steeply only after the roads are crowded, so if remote work and flexible hours could remove enough commuters from the roads at peak times, traffic congestion could be largely eliminated (ch. 7 [39]).

The key phrase in the above paragraph is "if nothing else changed." There are several drivers of vehicle travel demand that are likely to change, and that may make declining traffic congestion elusive. Specific to our findings, some former transit riders are likely to transition to car commuting in a post-pandemic world. Additionally, if workers are commuting on fewer days each week, they may choose to live further from their work location and drive further on the days they do go to the office. Probably most importantly, in the absence of policies such as congestion pricing, any reductions in traffic congestion in high-demand regions are likely to simply induce demand [40]. The net long-term effect of the pandemic on traffic congestion, then, is not likely to be large.

\subsection{Environmental Outcomes}

Environmental effects have largely been positive during the pandemic. Lockdowns have limited mobility and industry, leading to reduced emissions [41,42], although some negative effects around 
waste management have also been observed [43]. Longer-term, the environmental impact of the pandemic legacy is less clear.

As discussed above, increases in remote work could decrease vehicle travel and thus reduce tailpipe emissions, although this may be somewhat counterbalanced by induced demand caused by less-congested roadways.

Declining transit use produces poor environmental outcomes if former transit riders switch to driving, but a switch to biking, walking, or telecommuting is considerably more positive. Again, investments in safe infrastructure will be needed to support a switch to biking or walking.

A long-term reduction in air travel has positive environmental implications. Civil aviation is responsible for $2 \%$ of worldwide $\mathrm{CO}_{2}$ emissions, with total climate effects several times larger due to emissions of other greenhouse gases as well as formation of contrails at altitude [44]. Our results suggest a reduction in air travel is likely, particularly from business travelers. For environmental benefits to be realized, airlines will need to cut back their route networks, either by reducing frequency or number of destinations. If some of the loss in demand translates to reduced load factors rather than reduced air service, environmental benefits will be smaller. However, a reduction in demand for air travel may also lead airlines to more quickly phase out their least fuel efficient aircraft, something that has already occurred at some airlines [45].

An increase in online shopping will also have effects on the environment. A straight substitution of deliveries for in-person shopping trips can be environmentally advantageous, although this does depend on the number of stops made by each delivery vehicle, the number of items ordered simultaneously in each online shopping episode, and the metric used to evaluate environmental impact [46]. Furthermore, increases in online shopping are not necessarily direct substitutions for in-store shopping trips; they may be complements, or some parts of the shopping experience may move online while others do not $[47,48]$.

\section{Conclusion and Future Research}

This survey provides an important early look at how a sample of highly-educated US residents expect to change their behavior after the COVID-19 pandemic has subsided. While the sample is not representative of the US population as a whole, it focuses on a group of people whose behavior is important to understand in order to predict the long-term impact of the pandemic on our economy.

One unusual aspect of our survey was that we asked why respondents expect to change their behavior and what their experiences have been with current pandemic-induced changes to behavior. Understanding the reasons for behavioral change helps us understand whether reported changes to behavior are likely to persist far beyond the pandemic, or revert to pre-pandemic behavior as memory of the pandemic fades.

The results indicate that we are unlikely to completely return to our pre-pandemic way of life; at least some of the changes induced by the pandemic are likely to persist. People may shift from in-person working and shopping to online alternatives, and shift away from transit towards bicycling and walking. Air travel may be reduced, especially among business travelers. These changes will not be entirely unwelcome; our survey results also showed that many in our sample appreciate some aspects of the pandemic-induced changes to our way of life.

While these data provide an important early look at the long-term effects of the pandemic, there is significant opportunity for further research. The analysis presented in this article is entirely descriptive. In future research, we intend to build inferential models to understand the correlates of changes in behavior. For instance, job type, education, and income are likely highly correlated with the ability to work from home, and some industries may see larger drops in business air travel than others. Some demographic or attitudinal groups may be more comfortable with increasing their online shopping or learning than others. 
Expectations for future behavior are likely to evolve as the pandemic wears on, making continued data collection critical. We are doing this through both a larger, nationally-representative survey as well as by following up with respondents to this survey to understand how their expectations have evolved.

In addition, an important aspect of the pandemic is equity. COVID-19 has disproportionately affected racial minorities in the United States, likely because members of these groups lack the ability to social distance-due to working in jobs that are not conducive to remote work, and because they are often economically forced to live in crowded housing $[49,50]$. The data analyzed herein cannot speak to issues of equity, because they are collected almost exclusively from high-income, highly-educated respondents. Future research with the larger, nationally-representative sample we are currently collecting will include analysis of the equity implications of the pandemic.

Recovering from the pandemic will require a thorough understanding of how behavioral patterns are likely to shift in the future. Data from surveys such as this one help decisionmakers forecast the likely effects of the pandemic on long-term outcomes, allowing them to better plan for the future. Given our survey results, planning for a return to pre-pandemic conditions is inadvisable, as post-pandemic conditions are likely to differ.

Author Contributions: Conceptualization, D.S., M.W.C., and D.C.d.S.; methodology, M.W.C., D.S., D.C.d.S., L.M.; software, M.W.C., D.S., D.C.d.S., L.M.; validation, M.W.C., D.S., D.C.d.S., L.M.; formal analysis, M.W.C., D.S., D.C.d.S., L.M.; investigation, M.W.C., D.S., D.C.d.S., L.M.; resources, M.W.C., D.S., D.C.d.S., L.M.; data curation, M.W.C., D.S., D.C.d.S., L.M.; writing-original draft preparation, M.W.C., D.S., D.C.d.S., L.M.; writing-review and editing, M.W.C., D.S., D.C.d.S., L.M.; visualization, M.W.C.; supervision, D.S.; project administration, D.S.; funding acquisition, D.S. All authors have read and agreed to the published version of the manuscript.

Funding: The authors gratefully acknowledge support from the Center for Teaching Old Models New Tricks (TOMNET), a University Transportation Center sponsored by the U.S. Department of Transportation through Grant No. 69A3551747116, as well as from the Knowledge Exchange for Resilience at Arizona State University. This COVID-19 Working Group effort was also supported by the National Science Foundation-funded Social Science Extreme Events Research (SSEER) network and the CONVERGE facility at the Natural Hazards Center at the University of Colorado Boulder (NSF Award \#1841338). Any opinions, findings, and conclusions or recommendations expressed in this material are those of the authors and do not necessarily reflect the views of the NSF, SSEER, or CONVERGE.

Conflicts of Interest: The authors declare no conflict of interest.

\section{Appendix A}

To reduce 39 5-point Likert-scale-rated attitudinal statements to attitudinal constructs, we performed an exploratory factor analysis. To avoid losing many observations, rather than dropping all of the responses where respondents skipped any attitudinal question, we only dropped responses where respondents skipped all attitudinal questions, leaving us with 1290 responses with partial or complete attitudinal information. Of those, 1212 answered all attitudinal questions. To compute factor loadings for a dataset with missing values, we used the multiple imputation method and software of Nassiri et al. [51].

In order to perform a cluster analysis, we need not the factor loadings, but the factor scores for each respondent. We must again address missing data in this case, since computing the factor scores requires complete answers for all questions used in the factor analysis. We once again performed multiple imputation, and computed factor scores for each multiply-imputed dataset, then averaged those scores across all imputations for further analysis.

The factor analysis resulted in six factors, which are shown in Table A1. (Some attitudinal statements did not load on any factor, and are omitted from Table A1; all attitudinal statements used in factor analysis are listed in Table A2). A k-means cluster analysis of these factor scores divided the sample into the five attitudinal typologies used in this paper: suburban office lovers (15.8\%), unconcerned $(13.3 \%)$, urban shoppers $(22.9 \%)$, videoconferencers $(24.3 \%)$, and work-from-home extroverts (23.6\%). Table A3 reports the sociodemographic characteristics within each typology. 
Table A1. Pattern matrix loadings for exploratory factor analysis of attitudinal statements (Varimax rotation). Only loadings greater in magnitude than 0.3 are shown.

\begin{tabular}{|c|c|c|c|c|c|c|}
\hline & COVID-19-Concerned & $\begin{array}{c}\text { Environmentalist } \\
\text { /City-Lover }\end{array}$ & $\begin{array}{c}\text { Anti-Working } \\
\text { from Home }\end{array}$ & Pro-Videoconferencing & Extrovert & Pro-in-Person-Shopping \\
\hline Society is overreacting to the coronavirus & -0.74 & & & & & \\
\hline Everyone should just stay home as much as possible until the coronavirus has subsided & 0.74 & & & & & \\
\hline $\begin{array}{l}\text { Shutting down businesses to prevent the spread of coronavirus is not worth the } \\
\text { economic damage that will result }\end{array}$ & -0.68 & & & & & \\
\hline $\begin{array}{l}\text { I am concerned that friends or family members will have a severe reaction to the } \\
\text { coronavirus if they catch it }\end{array}$ & 0.46 & & & & & \\
\hline My friends and family expect me to stay at home until the coronavirus subsides & 0.44 & & & & & \\
\hline If I catch the coronavirus, I am concerned that I will have a severe reaction & 0.38 & & & & & \\
\hline $\begin{array}{l}\text { I am committed to using a less polluting means of transportation } \\
\text { (e.g., walking, biking, and public transit) as much as possible }\end{array}$ & & 0.72 & & & & \\
\hline Having shops and services within walking distance of my home is important to me & & 0.57 & & & & \\
\hline I am committed to an environmentally-friendly lifestyle & & 0.55 & & & & \\
\hline $\begin{array}{l}\text { Sometimes I feel guilty about the effects of my airplane trips on the environment } \\
\text { I feel safe on a bus or train } t\end{array}$ & & $\begin{array}{l}0.51 \\
0.44\end{array}$ & & & & \\
\hline Apartment living does not provide enough privacy & & -0.43 & & & & \\
\hline I like to have a yard at home. & & -0.39 & & & & \\
\hline Privacy is important to me when I travel + & & -0.31 & & & & \\
\hline It is hard to get motivated to work away from the main office & & & 0.7 & & & \\
\hline I like working from home & & & -0.65 & & & \\
\hline I enjoy the social interaction found at a conventional workplace & & & 0.56 & & 0.43 & \\
\hline Working at home may increase family conflicts & & & 0.39 & & & \\
\hline The time spent traveling to places provides a useful transition between activities & & & 0.34 & & & \\
\hline Online learning is a good alternative to high school- and college-level classroom instruction & & & & 0.76 & & \\
\hline Online learning is a good alternative to elementary-level classroom instruction & & & & 0.66 & & \\
\hline Video calling is a good alternative to visiting friends and family & & & & 0.58 & & \\
\hline Video calling is a good alternative to in-person business meetings & & & & 0.48 & & \\
\hline I like seeing people and having other people around me $\dagger$ & & & 0.3 & & 0.58 & \\
\hline I like to work on a team & & & & & 0.53 & \\
\hline I feel uncomfortable around people I do not know ${ }^{\dagger}$ & & & & & -0.43 & \\
\hline I like being outside $\dagger$ & & & & & 0.43 & \\
\hline I enjoy spending time with the people I live with & & & & & 0.33 & \\
\hline I dislike change & & & & & -0.3 & \\
\hline In-person shopping is usually a chore for me & & & & & & -0.56 \\
\hline Even if I do not end up buying anything, I still enjoy going to stores and browsing & & & & & & 0.55 \\
\hline I would not mind shopping for groceries online & & & & & & -0.37 \\
\hline
\end{tabular}

† respondents were instructed to answer these questions based on how they felt before the pandemic. 
Table A2. All attitudinal statements used in factor analysis.

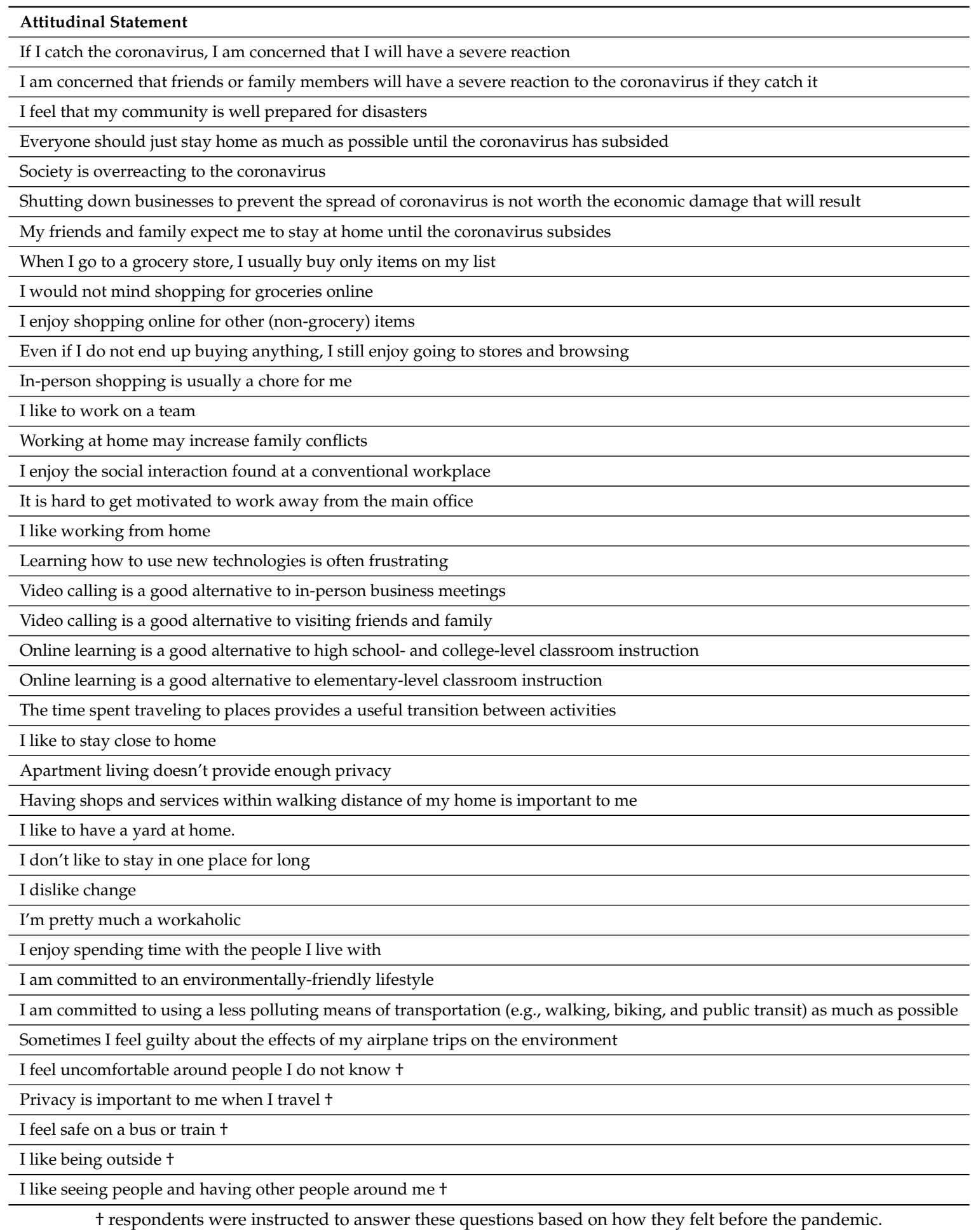


Table A3. Description of attitudinal cluster analysis results.

\begin{tabular}{|c|c|c|c|c|c|c|c|}
\hline & & Unconcerned & Videoconferencers & Urban Shoppers & Suburban Office Lovers & Work from Home Extroverts & Grand Total \\
\hline \multirow{2}{*}{ Sample Size } & $n$ & 172 & 313 & 296 & 204 & 305 & 1290 \\
\hline & $\%$ & $13.3 \%$ & $24.3 \%$ & $22.9 \%$ & $15.8 \%$ & $23.6 \%$ & $100.0 \%$ \\
\hline \multirow{6}{*}{ Attitudes +} & COVID-19-Concerned & -1.97 & 0.24 & 0.32 & 0.45 & 0.26 & 0.00 \\
\hline & Environmentalist/City-lover & -0.42 & -0.02 & 0.73 & -0.90 & 0.16 & 0.00 \\
\hline & Anti-working from home & 0.08 & -0.16 & 0.71 & 0.59 & -0.96 & 0.00 \\
\hline & Pro-videoconferencing & -0.05 & 1.13 & -0.36 & -0.56 & -0.41 & 0.00 \\
\hline & Extrovert & 0.13 & -0.40 & 0.15 & -0.52 & 0.53 & 0.00 \\
\hline & Pro-in-person-shopping & 0.28 & 0.18 & 0.44 & -0.68 & -0.31 & 0.00 \\
\hline \multirow{8}{*}{ Age } & $18-29$ & $11.6 \%$ & $15.7 \%$ & $34.5 \%$ & $21.6 \%$ & $10.2 \%$ & $19.1 \%$ \\
\hline & $30-39$ & $19.8 \%$ & $25.9 \%$ & $28.0 \%$ & $23.0 \%$ & $23.9 \%$ & $24.7 \%$ \\
\hline & $40-49$ & $23.8 \%$ & $19.2 \%$ & $9.8 \%$ & $23.0 \%$ & $23.6 \%$ & $19.3 \%$ \\
\hline & $50-59$ & $20.9 \%$ & $18.2 \%$ & $12.2 \%$ & $14.2 \%$ & $21.0 \%$ & $17.2 \%$ \\
\hline & $60-69$ & $12.8 \%$ & $13.4 \%$ & $4.7 \%$ & $10.3 \%$ & $15.4 \%$ & $11.3 \%$ \\
\hline & $70+$ & $2.9 \%$ & $4.2 \%$ & $5.4 \%$ & $2.9 \%$ & $2.3 \%$ & $3.6 \%$ \\
\hline & Age not reported & $8.1 \%$ & $3.5 \%$ & $5.4 \%$ & $4.9 \%$ & $3.6 \%$ & $4.8 \%$ \\
\hline & Average age & 45.75 & 44.74 & 38.28 & 41.92 & 46.11 & 43.28 \\
\hline \multirow{4}{*}{ Gender } & Female & $43.0 \%$ & $61.3 \%$ & $52.7 \%$ & $54.4 \%$ & $60.3 \%$ & $55.6 \%$ \\
\hline & Male & $47.1 \%$ & $33.9 \%$ & $41.6 \%$ & $42.6 \%$ & $36.4 \%$ & $39.4 \%$ \\
\hline & Other & $0.0 \%$ & $0.6 \%$ & $1.0 \%$ & $0.5 \%$ & $0.0 \%$ & $0.5 \%$ \\
\hline & Gender not reported & $9.9 \%$ & $4.2 \%$ & $4.7 \%$ & $2.5 \%$ & $3.3 \%$ & $4.6 \%$ \\
\hline \multirow{5}{*}{ Education } & Completed High school or less & $2.3 \%$ & $1.0 \%$ & $0.3 \%$ & $0.5 \%$ & $0.0 \%$ & $0.7 \%$ \\
\hline & Some college or technical school & $11.6 \%$ & $9.9 \%$ & $6.4 \%$ & $12.7 \%$ & $3.3 \%$ & $8.2 \%$ \\
\hline & Bachelor's degree(s) or some graduate school & $36.6 \%$ & $40.6 \%$ & $30.7 \%$ & $29.4 \%$ & $30.2 \%$ & $33.6 \%$ \\
\hline & Completed graduate degree $(\mathrm{s})$ & $40.7 \%$ & $46.0 \%$ & $58.1 \%$ & $52.9 \%$ & $63.9 \%$ & $53.4 \%$ \\
\hline & Education not reported & $8.7 \%$ & $2.6 \%$ & $4.4 \%$ & $4.4 \%$ & $2.6 \%$ & $4.1 \%$ \\
\hline \multirow{5}{*}{ Income } & Less than $\$ 25,000$ & $4.1 \%$ & $6.7 \%$ & $6.4 \%$ & $5.9 \%$ & $2.3 \%$ & $5.1 \%$ \\
\hline & $\$ 25,000$ to $\$ 74,999$ & $17.4 \%$ & $26.5 \%$ & $23.3 \%$ & $23.5 \%$ & $14.1 \%$ & $21.2 \%$ \\
\hline & $\$ 75,000$ to $\$ 149,000$ & $30.2 \%$ & $39.0 \%$ & $37.5 \%$ & $35.3 \%$ & $38.0 \%$ & $36.7 \%$ \\
\hline & $\$ 150,000$ or more & $33.7 \%$ & $21.4 \%$ & $23.6 \%$ & $29.9 \%$ & $40.3 \%$ & $29.4 \%$ \\
\hline & Income not reported & $14.5 \%$ & $6.4 \%$ & $9.1 \%$ & $5.4 \%$ & $5.2 \%$ & $7.7 \%$ \\
\hline \multirow{2}{*}{$\begin{array}{l}\text { Children in } \\
\text { household }\end{array}$} & No & $70.9 \%$ & $78.3 \%$ & $82.8 \%$ & $67.6 \%$ & $70.5 \%$ & $74.8 \%$ \\
\hline & Yes & $29.1 \%$ & $21.7 \%$ & $17.2 \%$ & $32.4 \%$ & $29.5 \%$ & $25.2 \%$ \\
\hline
\end{tabular}

† values indicated as average factor score within cluster divided by the standard deviation in the sample. 


\section{References}

1. Kraemer, M.U.; Yang, C.H.; Gutierrez, B.; Wu, C.H.; Klein, B.; Pigott, D.M.; Du Plessis, L.; Faria, N.R.; Li, R.; Hanage, W.P.; et al. The effect of human mobility and control measures on the COVID-19 epidemic in China. Science 2020, 368, 493-497.

2. Cartenì, A.; Di Francesco, L.; Martino, M. How mobility habits influenced the spread of the COVID-19 pandemic: Results from the Italian case study. Sci. Total Environ. 2020, 741, 140489.

3. Shamshiripour, A.; Rahimi, E.; Shabanpour, R.; Mohammadian, A.K. How is COVID-19 reshaping activity-travel behavior? Evidence from a comprehensive survey in Chicago. Transp. Res. Interdiscip. Perspect. 2020, 7, 100216, doi:10.1016/j.trip.2020.100216.

4. Gössling, S.; Scott, D.; Hall, C.M. Pandemics, tourism and global change: A rapid assessment of COVID-19. J. Sustain. Tour. 2020, 1-20. doi:10.1080/09669582.2020.1758708.

5. Owens, S.; Driffill, L. How to change attitudes and behaviours in the context of energy. Energy Policy 2008, $36,4412-4418$.

6. Barnes, W.; Gartland, M.; Stack, M. Old habits die hard: path dependency and behavioral lock-in. J. Econ. Issues 2004, 38, 371-377.

7. Polites, G.L.; Karahanna, E. Shackled to the status quo: The inhibiting effects of incumbent system habit, switching costs, and inertia on new system acceptance. MIS Q. 2012, 36, 21-42.

8. Kramer, A.; Kramer, K.Z. The potential impact of the Covid-19 pandemic on occupational status, work from home, and occupational mobility. J. Vocat. Behav. 2020, 119, 103442. doi:10.1016/j.jvb.2020.103442.

9. Amekudzi-Kennedy, A.; Labi, S.; Woodall, B.; Chester, M.; Singh, P. Reflections on Pandemics, Civil Infrastructure and Sustainable Development: Five Lessons from COVID-19 through the Lens of Transportation. 2020, doi:10.20944/preprints202004.0047.v1.

10. Gensler Research Institute. BRIEFING \#1: Back to the Office. 2020. Available online: https://www.gensler. com/uploads / document/695/file/Gensler-US-Work-From-Home-Survey-2020-Briefing-1.pdf (accessed on 5 October 2020).

11. Massachusetts Competitive Partnership. 100 Business Survey: COVID-19 Remote Work; Technical Report; Massachusetts Competitive Partnership: Boston, MA, USA, 2020. Available online: https:/ / 633a9a3b-a2234c7d-b77d-ce154f6a2f3c.filesusr.com/ugd/5c57db_f5a878bc3bb54bff92d7f8089d977a01.pdf (accessed on 26 August 2020).

12. Webber, M.M. The urban place and the nonplace realm. In Explorations into Urban Structure; University of Pennsylvania Press: Philadelphia, PA, USA, 1964; pp. 79-153. doi:10.9783/9781512808063-005.

13. Sassen, S. The Global City: New York, London, Tokyo, 2nd ed.; Princeton University Press: Princeton, NJ, USA, 2001.

14. Grashuis, J.; Skevas, T.; Segovia, M.S. Grocery shopping preferences during the COVID-19 pandemic. Sustainability 2020, 12, 5369. doi:10.3390/su12135369.

15. Nhamo, G.; Dube, K.; Chikodzi, D. Restaurants and COVID-19: A Focus on Sustainability and Recovery Pathways. In Counting the Cost of COVID-19 on the Global Tourism Industry; Springer: Cham, Switzerland, 2020; pp. 205-224.

16. Bureau of Labor Statistics. Industries at a Glance: Food Services and Drinking Places: NAICS 722. 2020. Available online: https:/ /www.bls.gov/iag/tgs/iag722.htm (accessed on 20 August 2020).

17. Berrebi, S.J.; Watkins, K.E. Who's Ditching the Bus? Transp. Res. Part A Policy Pract. 2020, 136, 21-34. doi:10.1016/j.tra.2020.02.016.

18. Savidge, N. Last-Minute Deal Saves Caltrain Tax. Will Voters Support It? San Jose Mercury News, 6 August 2020.

19. Taylor, B.D.; Garrett, M.; Iseki, H. Measuring Cost Variability in Provision of Transit Service. Transp. Res. Rec. 2000, 1735, 101-112. doi:10.3141/1735-13.

20. Pucher, J.; Dijkstra, L. Promoting Safe Walking and Cycling to Improve Public Health: Lessons from the Netherlands and Germany. Am. J. Public Health 2003, 93, 1509-1516. doi:10.2105/ AJPH.93.9.1509.

21. Schmitt, A. Right of Way: Race, Class, and the Silent Epidemic of Pedestrian Deaths in America; Island Press: Washington, DC, USA, 2020.

22. Diaz, J. Cities Close Streets to Cars, Opening Space for Social Distancing. The New York Times, 11 April 2020. 
23. Baruchman, M. Seattle Will Permanently Close 20 Miles of Residential Streets to Most Vehicle Traffic. The Seattle Times, 7 May 2020.

24. Transportation Security Administration. TSA Checkpoint Travel Numbers for 2020 and 2019. Available online: http://web.archive.org/web/20200515043024/https:/ / www.tsa.gov/coronavirus / passenger-throughput (accessed on 15 May 2015).

25. Adrienne, N.; Budd, L.; Ison, S. Grounded aircraft: An airfield operations perspective of the challenges of resuming flights post COVID. J. Air Transp. Manag. 2020, 89, 101921. doi:10.1016/j.jairtraman.2020.101921.

26. Airlines for America. Tracking the Impacts of COVID-19, Updated 5 October 2020.2020. Available online: https: / / www.airlines.org/wp-content/uploads/2020/03/A4A-COVID-Impact-Updates109.pdf (accessed on 5 October 2020).

27. Delta Air Lines. Delta Air Lines 2019 Form 10-K. 2020. Available online: https://s2.q4cdn.com/181345880/ files/doc_financials/2019/q4/DAL-12.31.2019-10K-NG-02.12.20-445pm-As-Filed-(1).pdf (accessed on 14 August 2020).

28. Aucejo, E.M.; French, J.; Ugalde Araya, M.P.; Zafar, B. The impact of COVID-19 on student experiences and expectations: Evidence from a survey. J. Public Econ. 2020, 191, 104271. doi:10.1016/j.jpubeco.2020.104271.

29. Mokhtarian, P.L.; Salomon, I. Modeling the Desire to Telecommute: The Importance of Attitudinal Factors in Behavioral Models. Transp. Res. Part A 1997, 31, 35-50. doi:10.1016/S0965-8564(96)00010-9.

30. Kitamura, R.; Mokhtarian, P.L.; Laidet, L. A Micro-Analysis of Land Use and Travel in Five Neighborhoods in the San Francisco Bay Area. Transportation 1997, 24, 125-158. doi:10.1023/A:1017959825565.

31. Handy, S.L.; Xing, Y. Factors Correlated with Bicycle Commuting: A Study in Six Small U.S. Cities. Int. J. Sustain. Transp. 2011, 5, 91-110. doi:10.1080/15568310903514789.

32. Barajas, J.M. Perceptions, People, and Places: Influences on Cycling for Latino Immigrants and Implications for Equity. J. Plan. Educ. Res. 2019, doi:10.1177/0739456X19864714.

33. Barron, J. As Office Space Shrinks, So Does Privacy for Workers. The New York Times, 22 February 2015.

34. Danielsson, C.B.; Chungkham, H.S.; Wulff, C.; Westerlund, H. Office Design's Impact on Sick Leave Rates. Ergonomics 2014, 57, 139-147. doi:10.1080/00140139.2013.871064.

35. Kurgat, E.K.; Sexton, J.D.; Garavito, F.; Reynolds, A.; Contreras, R.D.; Gerba, C.P.; Leslie, R.A.; Edmonds-Wilson, S.L.; Reynolds, K.A. Impact of a Hygiene Intervention on Virus Spread in an Office Building. Int. J. Hyg. Environ. Health 2019, 222, 479-485. doi:10.1016/j.ijheh.2019.01.001.

36. Viggers, H.; Keall, M.; Wickens, K.; Howden-Chapman, P. Increased House Size Can Cancel out the Effect of Improved Insulation on Overall Heating Energy Requirements. Energy Policy 2017, 107, $248-257$. doi:10.1016/j.enpol.2017.04.045.

37. Wilson, A.; Boehland, J. Small Is Beautiful: U.S. House Size, Resource Use, and the Environment. J. Ind. Ecol. 2005, 9, 277-287. doi:10.1162/1088198054084680.

38. Hirt, S.A. Zoned in the USA: The Origins and Implications of American Land-Use Regulation; Cornell University Press: Ithaca, NY, USA, 2014.

39. Transportation Research Board. In Highway Capacity Manual 2000: Metric Units; National Academies: Washington, DC, USA, 2000.

40. Downs, A. Stuck in Traffic: Coping with Peak-Hour Traffic Congestion; Brookings Institution Press: Washington, DC, USA, 2000.

41. Wang, Q.; Su, M. A Preliminary Assessment of the Impact of COVID-19 on Environment-A Case Study of China. Sci. Total Environ. 2020, 728, 138915. doi:10.1016/j.scitotenv.2020.138915.

42. Muhammad, S.; Long, X.; Salman, M. COVID-19 Pandemic and Environmental Pollution: A Blessing in Disguise? Sci. Total Environ. 2020, 728, 138820. doi:10.1016/j.scitotenv.2020.138820.

43. Zambrano-Monserrate, M.A.; Ruano, M.A.; Sanchez-Alcalde, L. Indirect Effects of COVID-19 on the Environment. Sci. Total Environ. 2020, 728, 138813. doi:10.1016/j.scitotenv.2020.138813.

44. International Civil Aviation Organization. Destination Green: The next Chapter; Technical Report; International Civil Aviation Organization: Montreal, QC, Canada, 2019.

45. Telford, T. British Airways Is Retiring Its Entire Fleet of 747s amid Slump in Air Travel. Washington Post, 17 July 2020.

46. Jaller, M.; Pahwa, A. Evaluating the Environmental Impacts of Online Shopping: A Behavioral and Transportation Approach. Transp. Res. Part D Transp. Environ. 2020, 80, 102223. doi:10.1016/j.trd.2020.102223. 
47. Couclelis, H. Pizza over the Internet: E-Commerce, the Fragmentation of Activity and the Tyranny of the Region. Entrep. Reg. Dev. 2004, 16, 41-54. doi:10.1080/0898562042000205027.

48. Mokhtarian, P.L. A Conceptual Analysis of the Transportation Impacts of B2C E-Commerce. Transportation 2004, 31, 257-284. doi:10.1023/B:PORT.0000025428.64128.d3.

49. Yancy, C.W. COVID-19 and African Americans. JAMA 2020, 323, 1891. doi:10.1001/jama.2020.6548.

50. Webb Hooper, M.; Nápoles, A.M.; Pérez-Stable, E.J. COVID-19 and Racial/Ethnic Disparities. JAMA 2020, 323, 2466. doi:10.1001/jama.2020.8598.

51. Nassiri, V.; Lovik, A.; Molenberghs, G.; Verbeke, G. On Using Multiple Imputation for Exploratory Factor Analysis of Incomplete Data. Behav. Res. Methods 2018, 50, 501-517. doi:10.3758/s13428-017-1013-4.

Publisher's Note: MDPI stays neutral with regard to jurisdictional claims in published maps and institutional affiliations.

(C) 2020 by the authors. Licensee MDPI, Basel, Switzerland. This article is an open access article distributed under the terms and conditions of the Creative Commons Attribution (CC BY) license (http:/ / creativecommons.org/licenses/by/4.0/). 